\title{
Limited Secondary Transmission of the Novel Coronavirus (SARS-CoV-2) by Asymptomatic and Mild COVID-19 Patients in Bhutan
}

\author{
Tshokey Tshokey, ${ }^{1 \star}$ Jamyang Choden, ${ }^{2}$ Kinley Dorjee, ${ }^{2}$ Pempa Pempa,${ }^{2}$ Pema Yangzom, ${ }^{2}$ Wangdi Gyeltshen, ${ }^{2}$ \\ Sonam Wangchuk, ${ }^{3}$ Tandin Dorji, ${ }^{2}$ and Dechen Wangmo ${ }^{2}$ \\ ${ }^{1}$ Jigme Dorji Wangchuck National Referral Hospital, Thimphu, Bhutan; ${ }^{2}$ Ministry of Health, Thimphu, Bhutan; ${ }^{3}$ Royal Center for Disease Control, \\ Thimphu, Bhutan
}

\begin{abstract}
As the COVID-19 pandemic continues, there is growing concordance and persisting conflicts on the virus and the disease process. We discuss limited transmissibility of the virus by asymptomatic and mild cases of COVID-19 patients in Bhutan. We followed up the secondary transmission of SARS-CoV-2 in the contacts of asymptomatic and mild COVID-19 patients in Bhutan. Bhutan had 33 confirmed COVID-19 cases in the country as of May 29, 2020. Of these, 22 $(67 \%)$ were females. Except the first two cases (American tourists), the rest were Bhutanese living outside the country. The mean age of the Bhutanese patients was 26.3 (range 16-33) years. Close contacts of 27 of the 33 cases were followed up for signs and symptoms and COVID-19 positivity. The first two cases had 73 and 97 primary contacts, respectively, and equal number of secondary contacts (224). From the third case, a mandatory 21-day facility quarantine was instituted, all primary contacts were facility quarantined, and there were no secondary contacts. In total, the 27 cases had 1,095 primary contacts and 448 secondary contacts. Of these, 75 individuals were categorized as definite high-risk contacts. Secondary transmission occurred in seven high-risk contacts. Therefore, the overall secondary transmission was $9.0 \%(7 / 75)$ and $0.6 \%(7 / 1,095)$ among the high-risk and primary contacts, respectively. No transmission occurred in the secondary contacts. In contrast to several reports indicating high transmissibility of SARS-CoV-2 in contacts of confirmed cases, the mostly young, asymptomatic, and mild cases of COVID-19 in Bhutan showed limited secondary transmission.
\end{abstract}

\section{INTRODUCTION}

The COVID-19 caused by the SARS-CoV-2 started as a cluster of unexplained pneumonia in late December 2019 in Wuhan, China. ${ }^{1}$ The outbreak spread quickly, and the WHO declared it as a public health emergency of international concern on January 30 , 2020 and as a pandemic on March 11, 2020. ${ }^{2}$ As of May 29, 2020, the pandemic has infected $5,657,529$ people and caused 356,254 deaths globally. ${ }^{2}$ As of this day, Bhutan had 33 confirmed cases of COVID-19, all of whom were imported. The first and the second cases were American tourist ${ }^{3}$ : the first was airlifted and the second has recovered and left the country. The rest were Bhutanese studying or living abroad who recently returned from the United Kingdom (two), the United States (one), the Middle East (29), and India (one). Except the first case, all other cases were either asymptomatic or mild in clinical presentation, and none progressed to severe disease.

The most recognized mode of transmission of COVID-19 is by respiratory droplets and droplet contact, although several debates on questionable airborne transmission continues. ${ }^{4-6}$ During the early periods of the outbreak, the WHO confirmed human-to-human transmission of the virus and a preliminary reproducible number $\left(R_{0}\right)$ of 1.4-2.5 was estimated. ${ }^{7}$ The basic $R_{0}$ in an analysis of early transmission dynamics in Wuhan was estimated to be 2.2 (95\% Cl: 1.4-3.9). ${ }^{8}$ When travel restriction was enforced, the median daily $R_{0}$ in Wuhan declined from 2.35 (95\% Cl: $1.15-4.77)$ to $1.05(0.41-2.39)$ after a week. ${ }^{9}$ Reports also indicated that COVID-19 has a higher effective $R_{0}$ than SARS with a comparable fatality rate. ${ }^{10} \mathrm{~A}$ report on a familial cluster of COVID-19 cases in China seems to indicate easy transmissibility of the disease even by asymptomatic cases. ${ }^{11}$ Data also suggested that COVID-19 is efficiently transmitted in the community, ${ }^{12}$ and the $R_{0}$ of

*Address correspondence to Tshokey Tshokey, Jigme Dorji Wangchuck National Referral Hospital (JDWNRH), Gongphel Lam, Thimphu 11001, Bhutan. E-mail: doc_tshokey@yahoo.com
COVID-19 was reported to be greater than that for infleunza. ${ }^{8}$ In Taiwan, an average secondary clinical attack rate of $0.9 \%$ (95\% Cl: 0.7-1.5) was reported, with a higher attack rate in those exposed within 5 days of symptom onset $(2.4 \%)$ than those exposed later (zero cases in 605 close contacts). The attack rate was also higher in family contacts $(13.6 \%)$ and nonhousehold contacts (8.5\%) than healthcare or other contacts. ${ }^{13}$

Bhutan's national preparedness and response plan for COVID19 is constantly reviewed based on emerging evidence. The most unique feature of Bhutan's strategy includes a mandatory 21-day facility quarantine for all incoming individuals. During the quarantine period, individuals were tested by RT-PCR on days $3-5$ and 13-14 and a rapid antibody test on day 22 (on completion of quarantine). In addition, an individual was tested on arrival at the point of entry (if symptomatic) and anytime during quarantine (if onset of symptoms reported). Secondary transmission of COVID19 among the close contacts of these asymptomatic or mild cases has been minimal. We describe these limited secondary transmissions by the asymptomatic to mild Bhutanese patients and attempt to explain this from different perspectives.

\section{METHODS}

This is a descriptive study related to the first 27 COVID19-confirmed cases in Bhutan. Ethical approval was not required for descriptive and noninterventional studies related to the COVID-19 pandemic.

At the time of detecting these cases, viral RNA was extracted from $140 \mu \mathrm{L}$ of nasopharyngeal swab collected in universal transport medium using a QIAamp viral RNA mini kit (QIAGEN, Hilden, Germany). SARS-CoV-2 viral genome was detected with the WHO-supplied MolBiol RT-PCR kit (TIBMolBio, Berlin, Germany) that targets $E$ and RdRp gene of SARS-CoV-2. The kit claimed a sensitivity of 3.8 and 5.5 RNA copies/ $\mu \mathrm{L}$ for $E$ and RdRp genes, respectively. The $E$ and RdRp genes were amplified under the following PCR conditions: $50^{\circ} \mathrm{C}$ for 30 minutes, $95^{\circ} \mathrm{C}$ for 2 minutes, followed by 45 cycles of $95^{\circ} \mathrm{C}$ for 15 
seconds, and $55^{\circ} \mathrm{C}$ for 30 seconds in the $A B I 7500$ Fast Dx RTPCR system (Thermofisher, Waltham, MA). Samples with Ct values of $\leq 40$ were considered positive.

A line list of the first 33 laboratory-confirmed COVID-19 patients in the country was prepared. Similarly, all contacts of the patients (mostly in facility quarantine) were followed and reviewed for onset of signs and symptoms and positivity for COVID-19 tests. The follow-up continued until the completion of the 21-day mandatory quarantine or more in all cases.

Of the 33 cases detected until May 30,2020, contacts of the first 27 cases were followed up and analyzed. Contacts were classified as primary (individuals coming in some form of contact with the confirmed cases such as conveyance in the same cars/flights, encounter in clinics, serving meals, or providing housekeeping services in hotels) or secondary (individuals coming in contact with the primary contacts). Among the primary contacts, further risk stratification was made for definite high-risk contacts such as driving in the same car, sitting in adjacent seats on flights, family members, close friends, and roommates in quarantine facilities. Each of these high-risk contacts was described individually in regard to the onset of signs and symptoms and testing for COVID-19. Results are presented as simple numerical values, percentages, and descriptions of individual case status as relevant.

\section{RESULTS}

Bhutan had 33 laboratory-confirmed cases of COVID-19 as of May 29, 2020. Of these, 22 (67\%) were females, indicating a definite female predominance of infected people. All cases were imported, and there was no community transmission at the time of this study. Except the first two cases who were American tourists (a 79-year-old man and a 59-year-old woman), the rest were all Bhutanese and of young age-group with a mean age of 26.3 (range 16-33) years. Of the 27 cases followed up and included in this study, 14 (52\%) were asymptomatic, 12 (44\%) were mild, and one (4\%) was moderate (later progressed to severe disease) in clinical presentation. Among those symptomatic, fever, sore throat, loss of smell, and gastrointestinal presentation were the common symptoms. The first and the second cases had 73 and 97 primary contacts, respectively, and equal number of secondary contacts (224) because they traveled together. From the third case, a mandatory 21-day facility quarantine was instituted, and positive cases did not have any secondary contacts because all people traveling together in the same flight were considered primary contacts. In total, the 27 cases had 1,095 primary contacts and 448 secondary contacts. Of the primary contacts, there were 75 definite high-risk contacts among the primary contacts. The details of the confirmed cases are presented in Table 1.

Every individual in description had been tested a minimum of three times with RT-PCR, unless they have turned positive before the next scheduled testing. From all these contacts, transmission occurred only in seven high-risk contacts. Therefore, the overall secondary transmission rate among the high-risk contacts was $9.0 \%(7 / 75)$, and that among the primary contacts was $0.6 \%$ $(7 / 1,095)$, and none $(0 / 448)$ among the secondary contacts. Of the seven positive cases, six of them tested positive with the normal incubation period (14 days) from last contact with a confirmed case and one tested positive on day 21 of exposure (Figure 1).

TABLE 1

Details of the first 27 COVID-19-confirmed cases in Bhutan

\begin{tabular}{|c|c|c|c|c|c|c|c|c|}
\hline Cases & $\begin{array}{c}\text { Age } \\
\text { (years) }\end{array}$ & Gender & Case origin & Disease category & Main symptoms & $\begin{array}{l}\text { Primary } \\
\text { contacts }\end{array}$ & $\begin{array}{l}\text { Secondary } \\
\text { contacts }\end{array}$ & $\begin{array}{l}\text { High-risk } \\
\text { contacts }\end{array}$ \\
\hline C0001 & 76 & M & Tourist (USA) & Moderate/severe & Gastrointestinal & 73 & 224 & 5 \\
\hline C0002 & 59 & $\mathrm{~F}$ & Tourist (USA) (partner of C0001) & Asymptomatic & - & 97 & 224 & 3 \\
\hline $\mathrm{C} 0003$ & 20 & $\mathrm{~F}$ & Bhutanese (London) & Mild & Fever and chills & 31 & 0 & 2 \\
\hline C0004 & 19 & $\mathrm{~F}$ & Bhutanese (London) & Mild & Anosmia & 28 & 0 & 1 \\
\hline C0005 & 16 & $\mathrm{~F}$ & Bhutanese (New York) & Asymptomatic & - & 16 & 0 & 2 \\
\hline C0006 & 24 & $\mathrm{~F}$ & Bhutanese (Dubai) & Mild & Sore throat & 24 & 0 & 3 \\
\hline C0007 & 24 & $\mathrm{M}$ & Bhutanese (Doha) & Mild & Anosmia & 14 & 0 & 2 \\
\hline C0008 & 27 & $M$ & Bhutanese (Dubai) & Asymptomatic & - & 24 & 0 & 2 \\
\hline C0009 & 27 & $\mathrm{~F}$ & Bhutanese (Dubai) & Asymptomatic & - & 24 & 0 & 2 \\
\hline C0010 & 25 & $\mathrm{M}$ & Bhutanese (Kuwait) & Asymptomatic & - & 37 & 0 & 3 \\
\hline C0011 & 27 & $\mathrm{~F}$ & Bhutanese (Dubai) & Mild & Fever and sore throat & 39 & 0 & 3 \\
\hline C0012 & 33 & $\mathrm{M}$ & Bhutanese (Dubai) & Asymptomatic & - & 36 & 0 & 4 \\
\hline C0013 & 23 & $\mathrm{~F}$ & Bhutanese (Abu Dhabi) & Mild & Fever and headache & 36 & 0 & 2 \\
\hline C0014 & 32 & M & Bhutanese (Doha) & Mild & Fever, sore throat, and body ache & 36 & 0 & 7 \\
\hline C0015 & 26 & $\mathrm{~F}$ & Bhutanese (Abu Dhabi) & Mild & Sore throat and diarrhea & 19 & 0 & 2 \\
\hline C0016 & 31 & $\mathrm{~F}$ & Bhutanese (Dubai) & Asymptomatic & - & 65 & 0 & 2 \\
\hline C0017 & 29 & $\mathrm{~F}$ & Bhutanese (Abu Dhabi) & Asymptomatic & - & 65 & 0 & 3 \\
\hline C0018 & 24 & $\mathrm{~F}$ & Bhutanese (Dubai) & Asymptomatic & - & 65 & 0 & 2 \\
\hline C0019 & 27 & $\mathrm{~F}$ & Bhutanese (Dubai) & Asymptomatic & - & 65 & 0 & 3 \\
\hline C0020 & 30 & M & Bhutanese (Doha) & Mild & Fever and diarrhea & 37 & 0 & 3 \\
\hline C0021 & 29 & $\mathrm{~F}$ & Bhutanese (Doha) & Asymptomatic & - & 36 & 0 & 5 \\
\hline C0022 & 30 & $\mathrm{~F}$ & Bhutanese (Abu Dhabi) & Asymptomatic & - & 45 & 0 & 3 \\
\hline C0023 & 28 & $\mathrm{~F}$ & Bhutanese (Abu Dhabi) & Asymptomatic & - & 45 & 0 & 2 \\
\hline C0024 & 34 & $\mathrm{~F}$ & Bhutanese (Dubai) & Asymptomatic & - & 36 & 0 & 2 \\
\hline $\mathrm{C} 0025$ & 23 & $M$ & Bhutanese (Kuwait) & Mild & Nose block and anosmia & 30 & 0 & 2 \\
\hline $\mathrm{C} 0026$ & 29 & $M$ & Bhutanese (Doha) & Mild & Fever and sore throat & 36 & 0 & 3 \\
\hline C0027 & 29 & $M$ & Bhutanese (Doha) & Mild & Nasal irritation & 36 & 0 & 2 \\
\hline Total & & & & & & 1,095 & 448 & 75 \\
\hline
\end{tabular}

$\mathrm{F}=$ Female; $\mathrm{M}=$ male. 

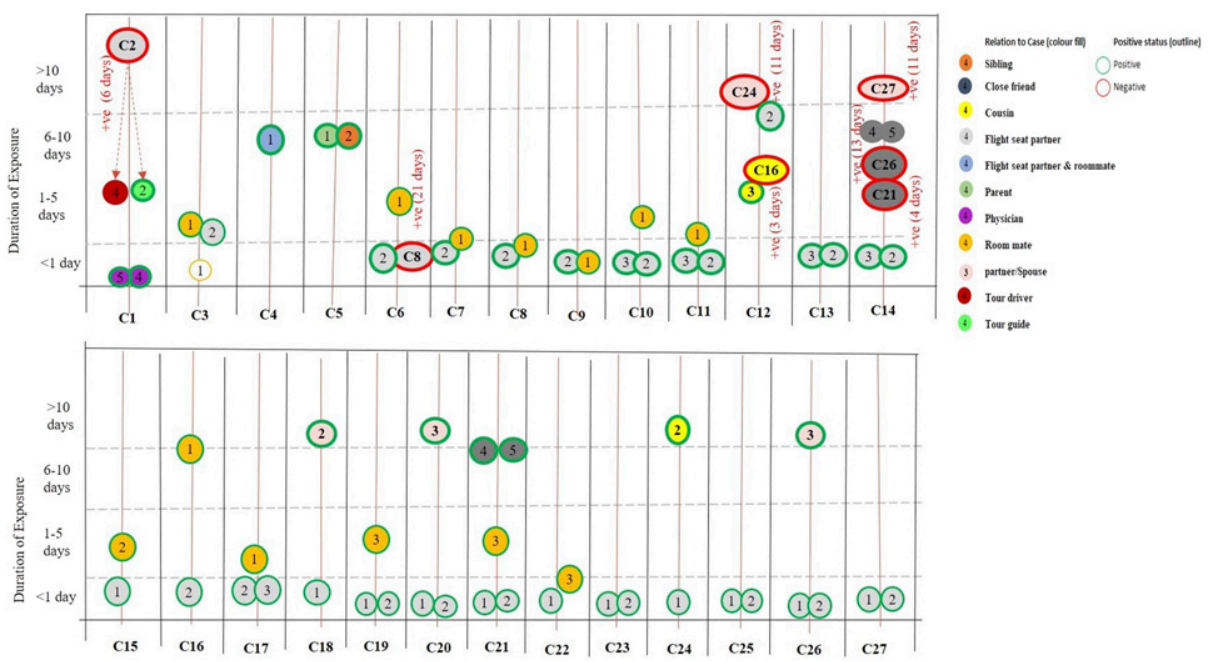

FIGURE 1. Relation between confirmed cases and contacts with time to positivity after last contact.

Definite close contacts with high risk for transmission of the virus from confirmed cases, their contact details, and transmission status are individually detailed in Table 2. Secondary transmission occurred commonly in partners/spouse (4/7), close friends (2/7), and flight seat partner (1/7). The observed Ct value of the sample and the presence of symptoms did not seem to affect the occurrence of secondary transmission.

\section{DISCUSSION}

Rapidly increasing cases of COVID-19 worldwide with shortening durations between doubling numbers of confirmed cases in many countries seem to indicate high transmissibility of COVID-19. Presymptomatic transmissions with cluster transmissions also suggested easy transmissibility even through vocal activities such as singing and choir groups. ${ }^{14,15}$ By contrast, our study argues that asymptomatic or mild cases may not transmit the virus easily. The limited secondary transmission of SARS-CoV-2 presented in our study has been deduced from observing and testing the close contacts of laboratory-confirmed COVID-19 patients up to 21 days or more in strict facility quarantine. All contacts have undergone constant monitoring for the onset of symptoms and scheduled testing (at least three RT-PCR tests) including the antibody testing at the end of the 21-day facility quarantine. Therefore, for an accepted mean incubation period of 5.2 (range 2-14) days ${ }^{8}$ for COVID-19 disease, a quarantine period of 21 days or more followed by testing would have not missed any cases, and the findings of this study hold much value.

This observation may be attributed to many factors such as clinical severity, race, younger patients, and living in high altitude which were opined to be protective against transmission and severity of COVID-19 clinical manifestations. In addition, the preventive measures such as using face masks, cough etiquette, and hand hygiene, which were already being widely promoted, could have had positive impact on preventing the transmission of the virus. Clinically, patients who are asymptomatic or mild with none or minimal cough, sneezing, or respiratory distress (with no labored breathing) probably do not transmit the virus easily because of the limited respiratory secretions or droplets expelled into the air. Racial differences in COVID-19 susceptibility and disease severity have been described in the Americas with African American individuals and, to a lesser extent, Latino individuals bearing a disproportionate burden of COVID-19-related outcomes. ${ }^{16}$ Such racial and ethnic effects may be relevant to the Bhutanese ethnicity who are uniquely adapted to the Himalayas. Epidemiological data from Tibet and high-altitude regions of Bolivia and Ecuador compared with lowland suggested that high-altitude inhabitants (+2,500 $\mathrm{m}$ above sea level) are less susceptible to develop severe adverse effect in acute SARSCoV-2 virus infection. This was likely because of physiological adaptations counterbalancing the hypoxic environment of high altitude that protect from severe impact of acute SARSCoV-2 virus infection. ${ }^{17}$ Bhutan has human settlement at altitudes of up to $3,700 \mathrm{~m}$ above mean sea level, ${ }^{18}$ and this relation to high altitude may provide an explanation for almost all asymptomatic to mild cases among all the 33 cases. In another Tibetan study, 36 of the 67 (54\%) COVID-19 patients were asymptomatic, with only seven (10\%) progressed to severe disease and recovered with no death. In addition, imported cases of COVID-19 in Tibetan patients were reported to be generally mild with absence of fever or radiologic abnormalities. ${ }^{19}$ This observation is also in concurrence with imported cases of COVID-19 in Bhutan, with all the 33 Bhutanese cases being asymptomatic to mild. Plausible explanations for asymptomatic to mild cases in the Bhutanese patients are age (all young patients, the oldest being 33 years) and universal childhood vaccinations with Bacillus Calmette-Guerin (BCG) and oral polio vaccine (OPV) vaccinations as part of the Expanded Program on Immunization, with high vaccine coverage. This conclusion is in line with the finding that countries with BCG and OPV vaccination had lesser cases and low mortality from COVID-19. ${ }^{20}$ Analysis on BCG concluded that countries without universal policies of BCG vaccination (Italy, the Netherlands, the United States) had been severely affected compared with countries with universal and long-standing BCG policies. BCG vaccination was also found to be associated with the number of reported COVID-19 cases in a country. ${ }^{21,22}$

A modeling in Singapore has shown that implementing a combined intervention of quarantining infected individuals and their family members, workplace distancing, and school 
TABLE 2

High-risk contacts and their SARS-CoV-2 transmission status

\begin{tabular}{|c|c|c|c|c|}
\hline Case & High-risk contacts & Contact description & Level of contact & COVID-19 transmission status \\
\hline \multirow[t]{5}{*}{ C0001 } & \multirow[t]{5}{*}{5} & Partner & Traveled together in flight, cruise, and car & $\begin{array}{l}\text { Asymptomatic but positive after } 6 \text { days of } \\
\text { last contact (C0002) }\end{array}$ \\
\hline & & Tour driver & Chauffeured the patient for 4 days & \multirow{4}{*}{$\begin{array}{l}\text { Asymptomatic and tested negative in } \\
\text { between and on } 28 \text { days of last contact } \\
\text { and discharged from quarantine }\end{array}$} \\
\hline & & Tour guide & Guided the patient for 4 days & \\
\hline & & Physician 1 & Examined and talked with the patient $>2$ & \\
\hline & & Physician 2 & $\begin{array}{l}\text { hours. In close proximity, the patient } \\
\text { had no face mask }\end{array}$ & \\
\hline \multirow[t]{2}{*}{ C0002 } & \multirow[t]{2}{*}{3} & Tour driver & Common contacts of cases C0001 and & \\
\hline & & Tour guide & $\begin{array}{l}\text { C0002 because case C0002 was the } \\
\text { partner of case C0001 }\end{array}$ & \\
\hline \multirow[t]{3}{*}{ C0003 } & \multirow[t]{3}{*}{2} & Roommate & Traveled in the same flight from London & \\
\hline & & & $\begin{array}{l}\text { and spent three nights together in } \\
\text { quarantine }\end{array}$ & \\
\hline & & Flight seat partner & Traveled in the same flight from Singapore & \\
\hline C0004 & 1 & Flight seat partner and roommate & Roommate in quarantine for 10 days & \\
\hline \multirow[t]{2}{*}{ C0005 } & \multirow[t]{2}{*}{2} & Mother & Lived together in New York, traveled in the & \\
\hline & & Brother & $\begin{array}{l}\text { same flight to Bhutan, and spent two } \\
\text { nights together in quarantine }\end{array}$ & \\
\hline \multirow[t]{3}{*}{ C0006 } & \multirow[t]{3}{*}{3} & Roommate & Roommate in quarantine for three nights & \multirow[b]{3}{*}{$\begin{array}{l}\text { Asymptomatic but tested positive on day } \\
21 \text { testing (C008) }\end{array}$} \\
\hline & & Flight seat partner & Traveled together from Dubai to Bhutan & \\
\hline & & Flight seat partner & & \\
\hline \multirow[t]{2}{*}{ C0007 } & \multirow[t]{2}{*}{2} & Roommate & Traveled together from Doha to Bhutan & \multirow{12}{*}{$\begin{array}{l}\text { Asymptomatic and tested negative in } \\
\text { between and on } 21 \text { days of last contact } \\
\text { and discharged from quarantine }\end{array}$} \\
\hline & & Flight seat partner & Traveled together from Doha to Bhutan & \\
\hline \multirow[t]{2}{*}{ C0008 } & \multirow[t]{2}{*}{2} & Roommate & Roommate in quarantine for 21 days & \\
\hline & & Flight seat partner & Traveled together from Dubai to Bhutan & \\
\hline \multirow[t]{2}{*}{ C0009 } & \multirow[t]{2}{*}{2} & Roommate & Roommate in quarantine for 21 days & \\
\hline & & Flight seat partner & Traveled together from Dubai to Bhutan & \\
\hline \multirow[t]{3}{*}{ C0010 } & 3 & Roommate & Roommate in quarantine for three nights & \\
\hline & & Flight seat partner & Traveled together from Kuwait & \\
\hline & & Flight seat partner & & \\
\hline C0011 & 3 & Roommate & Roommate in quarantine for 1 day & \\
\hline & & Flight seat partner & Traveled together from Dubai to Bhutan & \\
\hline & & Flight seat partner & & \\
\hline C0012 & 4 & Spouse & $\begin{array}{l}\text { Traveled together and quarantined in the } \\
\text { same facility for three nights }\end{array}$ & $\begin{array}{l}\text { Asymptomatic and tested positive on day } \\
11 \text { of quarantine (C0024) }\end{array}$ \\
\hline & & Flight seat partner & Traveled together from Dubai to Bhutan & $\begin{array}{l}\text { Asymptomatic and tested negative in } \\
\text { between and on } 21 \text { days of last contact } \\
\text { and discharged from quarantine }\end{array}$ \\
\hline & & Cousin & $\begin{array}{l}\text { Stayed and traveled together from Dubai } \\
\text { to Bhutan }\end{array}$ & $\begin{array}{l}\text { Asymptomatic and tested positive on day } \\
3 \text { (C0016) }\end{array}$ \\
\hline & & Cousin & & Asymptomatic and tested negative in \\
\hline C0013 & 2 & Flight seat partner & Traveled together from Dubai to Bhutan & between and on 21 days of last contact \\
\hline & & Flight seat partner & & and discharged from quarantine \\
\hline C0014 & 7 & Spouse & $\begin{array}{l}\text { Traveled together and quarantined in the } \\
\text { same facility for two nights }\end{array}$ & $\begin{array}{l}\text { Symptomatic and tested positive on day } \\
11 \text { of quarantine (C0027) }\end{array}$ \\
\hline & & Flight seat partner & Traveled together from Doha to Bhutan & Asymptomatic and tested negative in \\
\hline & & Flight seat partner & Traveled together from Doha to Bhutan & between and on 21 days of last contact \\
\hline & & Close friend & Lived together in Doha and traveled & and discharged from quarantine \\
\hline & & Close friend & logenter irom Dona to bnutan & Asvmntomatic but tested positive on dav \\
\hline & & vivos irterid & & 4 of quarantine (C0021) \\
\hline & & Close friend & & $\begin{array}{l}\text { Asymptomatic but tested positive on day } \\
13 \text { of quarantine }(\mathrm{C} 0026)\end{array}$ \\
\hline C0015 & 2 & Roommate & Roommate in quarantine for three nights & Asymptomatic and tested negative in \\
\hline & & Flight seat partner & Traveled together from Dubai to Bhutan & between and on 21 days of last contact \\
\hline C0016 & 2 & Flight seat partner and roommate & $\begin{array}{l}\text { Lived together, traveled on same flight } \\
\text { and quarantined in same room }\end{array}$ & and discharged from quarantine \\
\hline & & Flight seat partner & Traveled together from Dubai to Bhutan & \\
\hline C0017 & 3 & Flight seat partner & Traveled together from Dubai to Bhutan & \\
\hline & & Flight seat partner & & \\
\hline & & Roommate & Roommate in quarantine for three nights & \\
\hline C0018 & 2 & Spouse & $\begin{array}{l}\text { Traveled together and quarantined in the } \\
\text { same room for two nights }\end{array}$ & \\
\hline & & Flight seat partner & Traveled together from Dubai to Bhutan & \\
\hline C0019 & 3 & Flight seat partner & Traveled together from Dubai to Bhutan & \\
\hline & & Flight seat partner & & \\
\hline & & Roommate & Roommate in quarantine for three nights & \\
\hline
\end{tabular}


TABLE 2

Continued

\begin{tabular}{|c|c|c|c|c|}
\hline Case & High-risk contacts & Contact description & Level of contact & COVID-19 transmission status \\
\hline \multirow[t]{2}{*}{ C0020 } & 3 & Spouse & $\begin{array}{l}\text { Traveled together and quarantined in the } \\
\text { same room for two nights }\end{array}$ & \\
\hline & & $\begin{array}{l}\text { Flight seat partner } \\
\text { Flight seat partner }\end{array}$ & Traveled together from Doha to Bhutan & \\
\hline \multirow[t]{3}{*}{ C0021 } & 5 & $\begin{array}{l}\text { Flight seat partner } \\
\text { Flight seat partner }\end{array}$ & Traveled together from Doha to Bhutan & \\
\hline & & Roommate & Roommate in quarantine for three nights & \\
\hline & & $\begin{array}{l}\text { Close friend } \\
\text { Close friend }\end{array}$ & $\begin{array}{l}\text { Lived and traveled together from Doha to } \\
\text { Bhutan }\end{array}$ & \\
\hline \multirow[t]{2}{*}{ C0022 } & 3 & $\begin{array}{l}\text { Flight seat partner } \\
\text { Flight seat partner }\end{array}$ & Traveled together from Dubai to Bhutan & \\
\hline & & Roommate & Roommate in quarantine for 11 days & \\
\hline C0023 & 2 & $\begin{array}{l}\text { Flight seat partner } \\
\text { Flight seat partner }\end{array}$ & Traveled together from Dubai to Bhutan & \\
\hline C0024 & 2 & $\begin{array}{l}\text { Flight seat partner } \\
\text { Cousin }\end{array}$ & $\begin{array}{l}\text { Traveled together from Dubai to Bhutan } \\
\text { Lived and traveled together from Dubai to } \\
\text { Bhutan }\end{array}$ & \\
\hline C0025 & 2 & $\begin{array}{l}\text { Flight seat partner } \\
\text { Flight seat partner }\end{array}$ & Traveled together from Kuwait to Bhutan & \\
\hline \multirow[t]{2}{*}{ C0026 } & 3 & Spouse & $\begin{array}{l}\text { Traveled together and quarantined in the } \\
\text { same room for } 12 \text { days }\end{array}$ & \\
\hline & & $\begin{array}{l}\text { Flight seat partner } \\
\text { Flight seat partner }\end{array}$ & $\begin{array}{l}\text { Lived together and traveled together from } \\
\text { Doha to Bhutan }\end{array}$ & \\
\hline C0027 & 2 & $\begin{array}{l}\text { Flight seat partner } \\
\text { Flight seat partner }\end{array}$ & Traveled together from Doha to Bhutan & \\
\hline
\end{tabular}

closure after community transmission ensues could substantially reduce the number of SARS-CoV-2 infections. ${ }^{23}$ Bhutan's institution of these measures even before the onset of community transmissions has been highly effective in preventing the transmission and spread into the community. Bhutan received its first case of COVID-19 only on March 5, 2020, after a lot of planning and advocacy. By then, people have been educated on preventive measures. Therefore, to a certain extent, it is likely that the contacts of the cases would have been practicing all the preventive measures, which could mitigate the risk of transmission during their contact. In Tianjin (China), cluster outbreaks in families, workplace, transport vehicles, and other public places were reported. These findings emphasized that special attention should be paid to the cases from the same family, same workplace, or other places where clustering is likely to occur, and the epidemiological investigation should be carried out timely to confirm the cluster. It also recommended that the close contacts of the patients should be transferred to an assigned observation place in time for single-room isolation. ${ }^{24}$ These actions have been the key features of the COVID-19 prevention and control response in Bhutan and have been proven to be effective, with minimal community transmission to date.

This study is not short of limitations, the main related to the inclusion of primary and secondary contacts. All the cases in description were imported, and all secondary contacts were related to the first two cases. Beginning with the third case, all contacts were invariably included as primary contacts and put under mandatory facility quarantine on arrival at the point of entry into the country. This inclusion potentially biased the cohort and may have impacted the transmission rate. In addition, viral load could not be performed, and transmission dynamics based on Ct values and presence or absence of symptoms may need to be interpreted with caution.

Received June 15, 2020. Accepted for publication December 1, 2020.

Published online December 10, 2020.
Acknowledgments: We would like to acknowledge the contribution of several people in the technical advisory group, the outbreak investigation team, surveillance team, quarantine team of the Ministry of Health: the epidemiology unit, and the sample collection and testing team of the Royal Center for Disease Control. Publication charges for this article were waived due to the ongoing pandemic of COVID-19.

Authors' addresses: Tshokey Tshokey, Jigme Dorji Wangchuck National Referral Hospital, Thimphu, Bhutan, E-mail: doc_tshokey@ yahoo.com. Jamyang Choden, Kinley Dorjee, Pempa Pempa, Pema Yangzom, Wangdi Gyeltshen, Tandin Dorji, and Dechen Wangmo, Ministry of Health, Thimphu, Bhutan, E-mails: jchoden@jdwnrh.gov.bt, kdorjee@health.gov.bt, pemba@health.gov.bt, pyangzom@health.gov.bt, wgyeltshen@health.gov.bt, tandindorj@health.gov.bt, and dwangmo@ health.gov.bt. Sonam Wangchuk, Royal Center for Disease Control, Thimphu, Bhutan, E-mail: swangchuk@health.gov.bt.

This is an open-access article distributed under the terms of the Creative Commons Attribution (CC-BY) License, which permits unrestricted use, distribution, and reproduction in any medium, provided the original author and source are credited.

\section{REFERENCES}

1. He F, Deng Y, Li W, 2020. Coronavirus disease 2019: what we know? J Med Virol 92: 719-725.

2. World Health Organization, 2020. Coronavirus (COVID-19) Events as They Happen. Geneva, Switzerland: WHO. Available at: https://www.who.int/emergencies/diseases/novel-coronavirus2019/events-as-they-happen. Accessed May 19, 2020.

3. LeVine S, Dhakal GP, Penjor T, Chuki P, Namgyal K, Watts M, 2020. Case report: the first case of novel coronavirus disease (COVID-19) in Bhutan. Am J Trop Med Hyg 102: 1205-1207.

4. Bahl P, Doolan C, de Silva C, Chughtai AA, Bourouiba L, Maclntyre CR, 2020. Airborne or droplet precautions for health workers treating coronavirus disease 2019? J Infect Dis. doi: 10.1093/infdis/jiaa189.

5. Setti L, Passarini F, De Gennaro G, Barbieri P, Perrone MG, Borelli M, Palmisani J, Di Gilio A, Piscitelli P, Miani A, 2020. Airborne transmission route of COVID-19: why 2 meters/ 6 feet of interpersonal distance could not be enough. Int J Environ Res Public Health 17: 2932. 
6. Somsen GA, van Rijn C, Kooij S, Bem RA, Bonn D, 2020. Small droplet aerosols in poorly ventilated spaces and SARS-CoV-2 transmission. Lancet Respir Med 8: 658-659.

7. World Health Organization, 2020. Statement on the Meeting of the International Health Regulations (2005) Emergency Committee Regarding the Outbreak of Novel Coronavirus (2019-nCoV). Geneva, Switzerland: WHO. Available at: https://www.who.int/ news-room/detail/23-01-2020-statement-on-the-meeting-ofthe-international-health-regulations-(2005)-emergency-committeeregarding-the-outbreak-of-novel-coronavirus-(2019-ncov). Accessed May 22, 2020.

8. Li $Q$ et al., 2020. Early transmission dynamics in Wuhan, China, of novel coronavirus-infected pneumonia. N Engl J Med 382: 1199-1207.

9. Kucharski AJ et al., 2020. Early dynamics of transmission and control of COVID-19: a mathematical modelling study. Lancet Infect Dis 20: 553-558.

10. Cao Z, Zhang Q, Lu X, Pfeiffer D, Jia Z, Song H, Zeng DD, 2020. Estimating the effective reproduction number of the 2019-nCoV in China. medRxiv. doi: 10.1101/2020.01.27.20018952.

11. Bai Y, Yao L, Wei T, Tian F, Jin DY, Chen L, Wang M, 2020. Presumed asymptomatic carrier transmission of COVID-19. JAMA 323: 1406-1407.

12. Cowling BJ, Aiello A, 2020. Public health measures to slow community spread of COVID-19. J Infect Dis 221: 1749-1751.

13. Cheng HY, Jian SW, Liu DP, Ng TC, Huang WT; Team TC-19 Outbreak Investigation, $\mathrm{Lin} \mathrm{HH}, 2020$. High transmissibility of COVID-19 near symptom onset. medRxiv. doi: 10.1101/2020.03.18.20034561.

14. Wei WE, Li Z, Chiew CJ, Yong SE, Toh MP, Lee VJ, 2020. Presymptomatic transmission of SARS-CoV-2 - Singapore, January 23-March 16, 2020. MMWR Morb Mortal Wkly Rep 69: 411-415.

15. Read $R, 2020$. A choir decided to go ahead with rehearsal. Now dozens of members have COVID-19 and two are dead. Los Angeles Times, 29. Available at: https://www.latimes.com/ world-nation/story/2020-03-29/coronavirus-choir-outbreak. Accessed May 20, 2020.

16. Webb Hooper M, Nápoles AM, Pérez-Stable EJ, 2020. COVID-19 and racial/ethnic disparities. JAMA 323: 2466-2467.

17. Arias-Reyes $C$ et al., 2020. Does the pathogenesis of SAR-CoV-2 virus decrease at high-altitude? Res Physiol Neurobiol 277: 103443.

18. Bhutan Travel Gate, 2020. Bhutan Altitude and Bhutan Elevations. Available at: https://bhutantourpackages.travel/about-bhutan/ bhutan-elevation/. Accessed May 18, 2020.

19. Lei $Y$, Lan Y, Lu J, Huang X, Silang B, Zeng F, 2020. Clinical features of imported cases of coronavirus disease 2019 in Tibetan patients in the Plateau area. Medrxiv. doi: 10.1101/ 2020.03.09.20033126.

20. Afifi MA, Alqahtani RM, Alzamil MAM, Khorshid FA, Almarshedy SM, Alattas SG, Alrawaf TN, Shujaa A, Almohideb M, 2020. Correlation between polio immunization coverage and overall morbidity and mortality for COVID-19: an epidemiological study. SSRN Electron J. doi: 10.2139/ssrn.3584864.

21. Miller A, Reandelar MJ, Fasciglione K, Roumenova V, Li Y, Otazu $\mathrm{GH}, 2020$. Correlation between universal BCG vaccination policy and reduced morbidity and mortality for COVID-19: an epidemiological study. medRxiv. doi: 10.1101/2020.03.24.20042937.

22. Martinez MR, 2020. Has the Key to a Coronavirus Vaccine been Staring us in the Face for a Century? Euro News. Available at: https://www.euronews.com/2020/04/06/has-the-key-to-acoronoavirus-vaccine-been-staring-us-in-the-face-for-a-century. Accessed May 30, 2020.

23. Koo JR, Cook AR, Park M, Sun Y, Sun H, Lim JT, Tam C, Dickens $\mathrm{BL}, 2020$. Interventions to mitigate early spread of SARS-CoV-2 in Singapore: a modelling study. Lancet Infect Dis 20: 678-688.

24. Liu YF, Li JM, Zhou PH, Liu J, Dong XC, Lyu J, Zhang Y, 2020. Analysis on cluster cases of COVID-19 in Tianjin. Zhonghua Liu Xing Bing Xue Za Zhi 41: 653-656. 